\title{
Physiological performance and electrophoretic pattern of isoenzymes in Phaseolus vulgaris Lam. seeds treated with essential oil of Moringa oleifera Lam
}

\section{Desempenho fisiológico e padrão eletroforético de isoenzimas em sementes de Phaseolus vulgaris Lam. tratadas com óleo essencial de Moringa oleifera Lam}

\author{
Márcia Antonia Bartolomeu Agustini ${ }^{*}$; Marlene de Matos Malavasi ${ }^{2}$; \\ José Renato Stangarlin²; Adilson Ricken Schuelter²; Ubirajara Contro Malavasi²; \\ Heloisa Oliveira dos Santos ${ }^{3}$; Rucyan Walace Pereira ${ }^{4}$
}

\begin{abstract}
In order to investigate the effect of different doses of essential oil of Moringa oleifera (EOM) on physiological potential and the expression of isoenzymes in bean seeds, an experiment was conducted with two cultivars (Colibri and Campos Gerais) and seven treatments (bactericidal, fungicide and the doses $0,0.1,0.2,0.4$ and $0.8 \% \mathrm{EOM}$ ). Germination, first count of germination, germination speed index (GSI), emergence and emergence rate index (ERI) were evaluated in addition to the enzymes esterase (EST), alcohol dehydrogenase (ADH), superoxide dismutase (SOD) and isocitrate lyase (ICL) by electrophoresis. In an experiment conducted in the laboratory, the dose containing $0.4 \%$ EOM promoted germination and higher averages for first germination in seeds and GSI in the Colibri cultivar. However, the highest dose used $(0.8 \%)$ was responsible for the worst physiological performance by the cultivar. For Campos Gerais, increasing doses of essential oil stimulated germination, first count of germination and GSI. In the field, higher doses of essential oil gave higher germination percentages for the Colibri cultivar, not influencing the seeds of Campos Gerais. The ERI was not altered by the treatments with OEM and changes in the molecular forms of the isoenzymes were observed, with low expression values of bands for EST, ICL and ADH-related vigor, the germination of both cultivars, as well as increased expression of SOD, which is associated with reductions in germination.
\end{abstract}

Key words: Bean. Germination. Moringa. Vigor.

\section{Resumo}

A fim de investigar o efeito de diferentes doses de óleo essencial de Moringa oleifera (OEM) no potencial fisiológico e expressão de isoenzimas em sementes de feijão, conduziu-se um experimento com duas cultivares (Campos Gerais e Colibri) e sete tratamentos (bactericida, fungicida e as doses 0, 0.1, 0.2, 0.4 e $0.8 \%$ de óleo essencial). Foram avaliados a germinação, primeira contagem de germinação, índice de velocidade de germinação (IVG), emergência e índice de velocidade de emergência (IVE), além das enzimas esterase (EST), álcool desidrogenase (ADH), superóxido dismutase (SOD) e isocitrato liase (ICL) por meio de eletroforese. Em experimento conduzido em laboratório, a dose contendo $0.4 \%$ de

\footnotetext{
${ }^{1}$ Prof $^{a}$, Universidade Tecnológica Federal do Paraná, UTFPR, Medianeira, PR, Brasil. E-mail: marciaagustini@utfpr.edu.br

2 Profs., Universidade Estadual do Oeste do Paraná, UNIOESTE, Marechal Cândido Rondon, PR, Brasil.E-mail: marlenemalavasi@ yahoo.com.br; jose.stangarlin@unioeste.br; adilson_schuelter@yahoo.com.br; biramalavasi@yahoo.com.br

3 Prof ${ }^{a}$, Universidade Federal de Lavras, UFLA, Lavras, MG, Brasil. E-mail: heloisasantos@dag.ufla.br

${ }^{4}$ Discente, UFLA, Lavras, MG, Brasil. E-mail: rucyanwalace@yahoo.com.br

* Author for correspondence
} 
OEM promoveu incremento na germinação e maiores médias para primeira contagem de germinação e IVG nas sementes da cultivar Colibri. No entanto, a maior dose utilizada $(0.8 \%)$ foi responsável pelo pior desempenho fisiológico para a cultivar. Para Campos Gerais, as doses crescentes de óleo essencial estimularam a germinação, a primeira contagem de germinação e IVG. À campo, as doses de óleo essencial conferiram maior porcentagem de emergência para a cultivar Colibri, não influenciando as sementes da cultivar Campos Gerais. O IVE não sofreu alteração e modificações nas formas moleculares das isoenzimas foram observadas, estando os baixos valores de expressão de bandas para EST, ICL e $\mathrm{ADH}$, relacionadas ao maior vigor e germinação das sementes de ambas as cultivares, bem como, maior expressão de $\mathrm{SOD}$, associada à redução na germinação.

Palavras-chave: Feijão. Germinação. Moringa. Vigor.

\section{Introduction}

The bean (Phaseolus vulgaris Lam.) is a native legume of the Americas, and is an important protein source in the diet of the world's population. In Brazil, the world's largest bean producer, the area occupied by the crop of first, second and third harvests account for around 3.36 million hectares according to data from the Companhia Nacional de Abastecimento - CONAB for the year 2014, with production estimated at 3.56 million tons; of this total, more than half is made up of the carioca trade group, which is preferred by consumers in the South Central region of the country (CONAB, 2014).

In Paraná agriculture (the largest producer in the country), the bean is a major concern. It is the fourth culture in planted area and is mainly cultivated by small and medium producers, demanding family work and hired labor (SEAB, 2012).

However, the bean plant is susceptible to many diseases caused by fungi, bacteria and viruses transmitted internally and externally to the seed during the storage period in the field and that can directly influence its quality. Therefore, their productivity can be affected since there is a reduction in germination with a loss of seed vigor and deterioration of the same, given that poor seed quality is one cause of low productivity of bean crops in Brazil (SILVA et al., 2008).

Among microorganisms, fungi and bacteria that attack the bean seeds constitute important dissemination vehicles and the introduction of pathogens in an area. Thus, the seed is the appropriate structure to undergo processes or receive substances suitable for the preservation or improvement of their performance (seed treatment). However, bactericides and fungicides that are currently available for the treatment of seeds present major problems of environmental and human contamination and, because they are synthetic, their use is prevented in the organic sector. Thus, combined with global environmental awareness, research on natural control alternatives related to the preservation of beneficial fauna and elimination of their natural enemies has expanded greatly (MIGLIORINI et al., 2012).

Alternatively, it is necessary to seek sustainable ways of controlling diseases in various crops such as extracts and essential oils from plants with fungicidal and bactericidal properties in order to control phytopathogenic microorganisms associated with seeds.

Among vegetables with the potential to act as an antimicrobial is moringa (Moringa oleifera Lamarck). Essential oils, aqueous and methanolic extracts of this plant have shown positive results in the elimination of pathogens (fungi and bacteria) in experiments conducted mostly in vitro. However, despite the proven antimicrobial activity of many essential oils, they can also interfere with seed germination because they have allelopathic activity and have been used as antimicrobials in substrate germination or seed treatment. Grosso et al. (2010) emphasized that mono- and sesquiterpenes, the main constituents of essential oils, can affect physiological processes in plants. 
Therefore, to be effective in eliminating pathogens transmitted by the seed, an essential oil should present toxic effects to pathogenic microorganisms and should not adversely affect the physiological potential of the seeds as determined by germination and vigor tests.

In seed technology, isoenzymes play a critical role in the identification of processes that lead to understanding the physiological condition of the seeds; they can be used as molecular markers to elucidate events that occur during the germination process (ALBUQUERQUE et al., 2009) and may, in some cases, help in understanding the cause of reductions in vigor and viability (GALVÃO et al., 2014).

Among themost studied enzymes as physiological quality markers are those that work in the respiratory process, such as alcohol dehydrogenase; enzymes with specific functions in lipid metabolism such as the esterases and isocitrate lyase (ZORATO et al., 2007), and those which perform an important role in the response to oxidative stress, such as superoxide dismutase (CAETANO et al., 2005)
In this way, the aim of this work was to evaluate the action of different doses of the essential oil moringa on germination, vigor and isoenzyme activity by electrophoresis in bean seeds of the Colibri and Campos Gerais cultivars.

\section{Material and Methods}

For the experiments, the Agronomic Institute of Paraná - IAPAR provided bean seeds of the Carioca commercial group certified (C2) and produced in northern Paraná from the 2013 harvest. Among the seven cultivars IAPAR 81, IPR Andorinha, IPR Campos Gerais, IPR Colibri, IPR Tangará, IPR Curió and IPR 139 it was decided to choose only two thatpossessed distinct germination and viability and met the MAPA specification (BRASIL, 2005) for marketing C2 seeds.

In order to select two cultivars to receive treatment with essential oil, the physiological potential and sanitary quality of seven bean cultivars of the carioca commercial group were evaluated, the results of which are shown in Table 1.

Table 1. Bayesian a posteriori estimates for germination percentage, first count (\%) electrical conductivity $\left(\mathrm{ms}^{-1} \mathrm{~g} \mathrm{~cm}^{-}\right.$ $\left.{ }^{1}\right)$ and fungal infection (\%) of stored bean seeds, according to cultivars.

\begin{tabular}{lcccc}
\hline \multicolumn{1}{r}{ Cultivar } & \% Germination & First count $(\%)$ & $\begin{array}{c}\text { Electrical } \\
\text { conductivity }\end{array}$ & $\begin{array}{c}\text { Fungal infection } \\
(\%)\end{array}$ \\
\hline IPR 81 & $91.79^{\mathrm{b}}$ & $0.746^{\mathrm{c}}$ & $91.91^{\mathrm{c}}$ & $16,25^{\mathrm{a}}$ \\
Campos Gerais & $83.34^{\mathrm{c}}$ & $1.766^{\mathrm{b}}$ & $107.20^{\mathrm{bc}}$ & $13,25^{\mathrm{b}}$ \\
Colibri & $99.26^{\mathrm{a}}$ & $4.105^{\mathrm{a}}$ & $103.00^{\mathrm{c}}$ & $13,00^{\mathrm{b}}$ \\
Tangará & $72.64^{\mathrm{d}}$ & $0.075^{\mathrm{e}}$ & $123.30^{\mathrm{ab}}$ & $19,25^{\mathrm{a}}$ \\
IPR 139 & $89.80^{\mathrm{b}}$ & $1.368^{\mathrm{b}}$ & $90.88^{\mathrm{c}}$ & $8,25^{\mathrm{d}}$ \\
IPR Andorinha & $84.58^{\mathrm{c}}$ & $0.249^{\mathrm{d}}$ & $88.75^{\mathrm{c}}$ & $6,25^{\mathrm{d}}$ \\
IPR Curió & $73.88^{\mathrm{d}}$ & $0.025^{\mathrm{e}}$ & $137.50^{\mathrm{a}}$ & $10,75^{\mathrm{c}}$ \\
\hline
\end{tabular}

${ }^{1}$ Proportions followed by different lowercase letters in the column are statistically different by Bayesian comparisons, at $5 \%$ probability.

In order to receive the different treatments containing doses of essential oil of moringa, beans from the carioca commercial group were selected (IPR Colibri and IPR Campos Gerais) that presentedsimilar percentages of contamination by fungi of the genera Rhizopus sp., Penicillium sp., Fusarium sp., Alternaria sp., Aspergillus flavus, Aspergillus ochraceus and Aspergillus niger after testing for quality assessment of health (blotter test method) - RSA (BRASIL, 2009) and different 
physiological potentials, thus justifying the need for seed treatment for protection against pathogens.

\section{Treatment of bean seeds}

The essential oil of moringa leaves was obtained by the Clevenger type of extractor and its compounds were characterized using gas chromatography-mass spectrometry at the Chemical Institute of USP.

An emulsion was prepared containing sterile distilled water and Tween $80(0.5 \%)$ in volumes of $100,99.95,99.90,99.80$ and $99.60 \mathrm{ml}$, plus the doses $0 \mu 1,50 \mu 1,100 \mu 1,200 \mu l$ and $400 \mu 1$ of essential oil of moringa, which amounted to $0,0.1$, $0.2,0.4$ and $0.8 \%$. Other treatments consisted of a fungicide and bactericide used for seed treatment according to the recommendations of the Ministério de Agricultura, Pecuária e Abastecimento - MAPA (2003); the fungicide Vitavax Thiram 200 SC and bactericidal Kocide WDG were applied according to the manufacturer's instructions.

The bean seeds and treatments were placed in plastic bags and submitted to manual agitation for 3 minutes, then left to dry at room temperature and subjected to the vigor and viability tests.

Viability and vigor of seeds after treatment with essential oil

Viability and vigor tests of treated seeds ( $\%$ germination, germination speed index, first count, emergence percentage and emergence speed index) were performed following the methodology of RSA (BRASIL, 2009). Assays were performed in April 2014 in the Biology Laboratory of Universidade Tecnológica Federal do Paraná - UTFPR, campus Medianeira.

The germination test was conducted using eight samples of 50 seeds and a germination chamber of BOD at a temperature of $25^{\circ} \mathrm{C}$ with a photoperiod of $12 \mathrm{~h}$ /light on germitest paper. To this end, we used three sheets of paper to form a roll that had been moistened with 2.5 times its weight in distilled water before sowing, according to RSA (BRASIL, 2009).

The first count, which was conducted jointly with the germination test, considered normal seedlings on the fifth day after sowing (those with all of the essential structures well developed, complete and proportional were considered to be normal seedlings). The results for germination percentage and first count were expressed as percentages.

The germination speed index (GSI) followed the methodology of Maguire (1962), which calls for adoption of the equation: GSI $=\mathrm{G} 1 / \mathrm{G} 2+\mathrm{N} 1 /$ $\mathrm{N} 2+\ldots+\mathrm{Gn} \mathrm{Nn}$, where G1, G2, and Gn are the number of germinated seedlings computed in the first, second and last count, respectively, and N1, $\mathrm{N} 2$, and $\mathrm{Nn}$ are the number of days from sowing to the first, second and last count, respectively.

In September 2014, in order to determine the field emergence and emergence speed index (ESI), four replicates of 50 seeds were used in each treatment described, sown in rows $1.2 \mathrm{~m}$ apart between $0.4 \mathrm{~m}$ lines and with 15 seeds per meter. The counts to determine the GSI were performed daily until the 15th day after sowing, considering seedlings that had cotyledons above the ground, in the open position, releasing the primary leaves.

The emergence speed index (ESI) was calculated as described by Nakagawa (1994), where ESI = E1 / $\mathrm{E} 2+\mathrm{N} 1 / \mathrm{N} 2+\ldots \mathrm{En} / \mathrm{Nn} . \mathrm{E} 1, \mathrm{E} 2$, and En indicate the number of normal seedlings that emerged in the first count, the second count and the last count, respectively. $\mathrm{N} 1, \mathrm{~N} 2, \ldots \mathrm{Nn}$ indicate the number of days from sowing to first, second and last count, respectively.

\section{Isoenzyme electrophoresis}

Assessing the activities of esterase enzymes, superoxide dismutase, alcohol dehydrogenase, isocitrate lyase and superoxide dismutase was carried out at the Central Seed Laboratory of the 
Universidade Federal de Lavras - UFLA in June 2014.

Treated seeds of both cultivars (IPR Colibri and IPR Campos Gerais) (50 seeds in each treatment) were maintained for 24 hours in a germination chamber at $25^{\circ} \mathrm{C}$ with a photoperiod of $12 \mathrm{~h} /$ light on germitest paper rolls. They were then macerated in a mill in the presence of liquid nitrogen and the antioxidant Polyvinyl pirrolidone (PVP) according to the methodology described by Muniz et al. (2007).

Here, $100 \mathrm{mg}$ of crushed sample was used, to which $300 \mu \mathrm{l}$ of $0.2 \mathrm{M}$ Tris-HClpH 8, extract and $0.1 \%$ beta-mercaptoethanol was added (MENEZES et al., 2008). The mixtures were vortexed and kept in the freezer at $-84^{\circ} \mathrm{C}$, and subsequently centrifuged at $21910.2 \mathrm{~g}$ for 30 minutes at $4{ }^{\circ} \mathrm{C}$ (MUNIZ et al., 2007).

The electrophoretic run was developed in polyacrylamide gels of $7.5 \%$ (separating gel) and $4.5 \%$ (concentrator gel). The gel buffer/electrode system used was $0.2 \mathrm{M}$ Tris- $\mathrm{HCl} \mathrm{pH} 8$, to which $50 \mu$ of bean samples were applied and runs were made at $150 \mathrm{v}$ for 4 hours. After the run, the gels were revealed to the enzymatic system according to the methodology of Alfenas et al. (1996).

\section{Experimental design and statistical procedures}

Atotal of 2800 carioca bean seeds were distributed in a completely randomized design (CRD), with seven treatments (cultivars) and four replicates of 50 seeds per experimental unit, to evaluate the electrical conductivity, germination percentage, first count of germination and tetrazolium test.

For the analysis of the seven cultivars, data from tetrazolium, \% germination and first count of germination were adjusted using binomial distribution. In turn, it was considered that the electrical conductivity data followed a normal probability distribution.
For viability assays and vigor after treatment with essential oil, a total of 8400 bean seeds were used, distributed in CRD to first count, \% germination and germination speed index (GSI), and in a randomized block design (RBD) for $\%$ of emergency and emergency speed index field (ESI).

A factorial scheme $(2 \times 7)$ was used, with fourteen treatments, eight replicates and 50 seeds per treatment. The treatments consisted of combinations of bean cultivars (Colibri and Campos Gerais) and seven classes of structured factor (SF), composed of: SF1: $0 \%$ essential oil of moringa (EOM) or control treatment; SF2: 0.1\% EOM; SF3: $0.2 \%$ of EOM; SF4: $0.4 \%$ of EOM; SF5: $0.8 \%$ of EOM; SF6: Fungicide and SF7: bactericide.

The statistical model used was: $\mathrm{Y}_{\mathrm{ijk}}=\mathrm{m}+\mathrm{C}_{\mathrm{i}}+$ $\mathrm{FE}_{\mathrm{j}}+\mathrm{CFE}_{\mathrm{ij}}+\mathrm{e}_{\mathrm{ijk}}$, where, $\mathrm{Y}_{\mathrm{ijk}}=$ average note in class $\mathrm{i}$ bean cultivars, $\mathrm{j}$ structured factors and $\mathrm{k}$ repetitions; $\mathrm{m}=$ general average; $\mathrm{Ci}=$ Effect of cultivating; $\mathrm{i}=$ $(1,2) ; E j F=$ structured factor effect; $j=(1,2,3,4$, 5, 6 and 7); CFEij = interaction effect of farming with the structured factor and Eijk = random error associated with each observation ijk.

After treatment of the seed data from the data from \% germination, GSI, ESI and first count were adjusted using binomial distribution, while for ESI the adjustment was made by the normal probability distribution.

The following statistical analysis was performed using Bayesian inference. Multiple comparisons were made between the posterior distributions of proportions and considered different at the 5\% level of significance factor classes whose credibility intervals for the mean differences did not include zero.

Obtaining the marginal posterior distributions for all parameters was performed using the $R$ program Brugs package ( $\mathrm{R}$ DEVELOPMENT CORE TEAM, 2007). Iteratively, 400,000 values were generated by an MCMC (Chain Monte Carlo Markov) process, considering a sampling discard 
(burn) of 40,000 heels with two initial values, i.e. the sample size was 200,000 chains of generated values. The convergence of the chains was verified by the CODA program package $\mathrm{R}$, by the criteria of Heidelberger and Welch (1983), together with the Geweke criterion.

\section{Results and Discussion}

Germination and vigor of seeds treated with essential oil

The results for percentage of common bean seed germination of cultivars Colibri and Campos Gerais treated with essential oil of moringa are shown in Table 2 .

Table 2. Bayesian a posteriori estimates for proportion and credible intervals (percentiles 2.5 and 97.5\%) in the percentage of bean seed germination of cultivars Colibri and Campos Gerais treated with essential oil of moringa, according to the structured factors ${ }^{1}$.

\begin{tabular}{|c|c|c|c|c|c|c|}
\hline \multirow{2}{*}{$\begin{array}{l}\text { Structured } \\
\text { factor }\end{array}$} & \multicolumn{3}{|c|}{$\begin{array}{l}\text { Colibri cultivar } \\
\text { Germination }(\%)\end{array}$} & \multicolumn{3}{|c|}{$\begin{array}{c}\text { Campos Gerais cultivar } \\
\text { Germination (\%) }\end{array}$} \\
\hline & Proportion & $\begin{array}{c}\text { Percentile } \\
2.5 \%\end{array}$ & $\begin{array}{l}\text { Percentile } \\
97.5 \%\end{array}$ & Proportion & $\begin{array}{c}\text { Percentile } \\
2.5 \%\end{array}$ & $\begin{array}{l}\text { Percentile } \\
97.5 \%\end{array}$ \\
\hline $0 \%$ EOM & $98.51^{\mathrm{abA}}$ & 97.10 & 99.45 & $80.60^{\text {e }}$ & 74.48 & 82.48 \\
\hline $0.1 \%$ EOM & $94.28^{\mathrm{cd} \mathrm{A}}$ & 91.82 & 96.32 & $84.82^{\text {bcd B }}$ & 81.16 & 88.17 \\
\hline $0.2 \%$ EOM & $98.01^{\mathrm{ab} \mathrm{A}}$ & 96.43 & 99.13 & $85.08^{\mathrm{bcd} B}$ & 81.44 & 88.39 \\
\hline $0.4 \%$ EOM & $99.25^{\mathrm{aA}}$ & 98.21 & 99.85 & $88.07^{\mathrm{abc} B}$ & 84.73 & 91.07 \\
\hline $0.8 \%$ EOM & $90.54^{\mathrm{eA}}$ & 87.49 & 93.21 & $91.05^{\mathrm{aA}}$ & 88.08 & 93.64 \\
\hline Fungicide & $98.51^{\mathrm{ab} \mathrm{A}}$ & 97.11 & 99.45 & $89.05^{\text {ab B }}$ & 85.82 & 91.91 \\
\hline Bactericidal & $93.79^{\text {de A }}$ & 91.23 & 95.93 & $83.33^{\text {cde B }}$ & 79.54 & 86.81 \\
\hline
\end{tabular}

${ }^{1}$ Proportions followed by different lowercase letters in the column and uppercase in line are statistically different by Bayesian comparisons, at 5\% probability; EOM: essential oil of moringa.

The best germination percentage in the Colibri cultivar was found in the seeds that received a dose corresponding to $0.4 \%$ EOM; no statistical differences were seen between treatments with 0.0 and $0.2 \% \mathrm{EOM}$ and fungicide. In turn, treatment doses of 0.1 and $0.8 \%$ EOM and bactericide had the lowest percentage of germination.

Even with the reduction in germination observed as a function of treatment with $400 \mu$ l of essential oil $(0.8 \%$ EOM $)$, it was noted that the seeds had good germination potential (over $90 \%$ ), meeting the minimum requirements for marketing required by MAPA (BRASIL, 2005).

With cultivar Campos Gerais, a dose of $0.8 \%$ EOM was statistically higher than otherdoses of $0.0,0.1$ and $0.2 \%$ EOM as well as treatment with bactericide. Noteworthy, the control treatment showedless germination than seeds treatment with essential oil, suggesting that chemical components present in the essential oil of moringa may have acted to stimulate seed germination, confirming the results of An et al. (1993), who reported that at low concentrations of plant allelochemicals, they can act as a stimulator.

This stimulus was also observed by Steffen et al. (2010) in eucalyptus essential oil on the germination and initial growth of Eucalyptus grandis seedlings, as well as by Mairesse (2005), who observed stimulation of lettuce seed germination treated with marcela extract and grass vine.

The highest percentage of germination due to the essential oil, presented by the Colibri cultivar, can be related to the fact that this cultivar presented better germination in the initial analysis.

The responses observed to the stimulus on germination followed by a decrease as a function 
of the doseof essential oil observed in the Colibri cultivar, and the increments observed in Campos Gerais germination, may suggest allelopathy, since this is described as a combination of inhibitory and stimulatory chemical interactions, such as one plant over another through chemical compounds. However, the chemical composition of the moringa essential oil did not indicate large levels of allelopathy; its chemical composition includes only small percentages of monoterpenes $(3.77 \%)$, and sesquiterpenes $(9.15 \%)$.

Present in high proportions in the essential oil (values above 60\%), according to Weidenhamer et al. (1993), terpenes are potentially a function of allelopathic agents that can cause extensive damage to cell membranes and respiratory processes; Paudel and Gupta (2008) stated that the regulation of hydrolytic enzymes is essential for the occurrence of germination, thus demonstrating that the presence of the compound alone is not sufficient, but that it must be at a precise amount to cause physiological or biochemical damage.

Linalool in the essential oil of moringa was also quoted by Rosado et al. (2009) to be responsible for the phytotoxic effect observed in tomato seedling, lettuce and melissa; however, this chemical component composes more than $78 \%$ of the essential oil of Ocimum basilicum.

Thus, we emphasize that even if the seed makes contact with the treatment for a short period of time (three minutes), the essential oil has the ability to engage its integument; during soaking, in the same way as in the germination process, its components are able to diffuse to the cotyledons and cause changes that result in different germination rates.

Changes in germination patterns reflect changes in entire metabolic pathways and processes that are considered important for the development of the embryo, directly affecting ontogenesis
(FERREIRA; AQUILA, 2000). These changes may be related to effects on the permeability of membranes, transcription and translation of genetic material, enzymatic reactions and cellular respiration (RIZVI; RIZVI, 1992).

For Isman et al. (2001), substances derived from the secondary metabolism of the plant and present in the essential oil can act to inhibit the germination of plants, among other functions, among which may be included stimulus. However, despite being influenced, according to Ferreira and Aquila (2000), germination is the stage of plant development that is least sensitive to the action of allelochemicals.

There were differences in the germination behavior of the cultivars due to the use of different doses of moringa essential oil (Table 2). Except for the dose with $0.8 \% \mathrm{EOM}$, the Colibri cultivar was statistically superior to Campos Gerais with respect to germination percentage. Moreover, it also showed higher percentages of germination and vigor in analyses that initially characterized the bean cultivars (Table 1), justifying the differences found in the percentage of seed germination with essential oil use. However, it can be observed that the less vigorous seeds (Campos Gerais) responded better to the essential oil components, considering that there were higher percentages compared to the control treatment. Nevertheless, Mazzafera (2003) reported that the effect on the seeds could be less vigorous.

It is emphasized that the resistance or tolerance of metabolites present in essential oils is specific, existing in species that are more or less sensitive than others; in this case, while working with the same kind, there was no difference in response between cultivars.

The vigor (first count of germination and germination speed index) of bean seeds due to the use of different doses of essential oil of moringa, fungicide and antibiotics is shown in Table 3. 
Table 3. Bayesian a posteriori estimates for the proportion of first count and GSI in bean seeds of Colibri and Campos Gerais cultivars treated with essential oil of moringa, according to the structured factors ${ }^{1}$.

\begin{tabular}{|c|c|c|c|c|}
\hline \multirow{2}{*}{ Structured factor } & \multicolumn{2}{|c|}{ Colibri Cultivar } & \multicolumn{2}{|c|}{ Campos Gerais Cultivar } \\
\hline & First count $(\%)$ & GSI & First count $(\%)$ & GSI \\
\hline $0 \%$ EOM & $0.995^{\mathrm{d} \mathrm{B}}$ & $7.35^{\mathrm{dA}}$ & $0.2388^{\mathrm{cA}}$ & $6.64^{\mathrm{abB}}$ \\
\hline $0.1 \% \mathrm{EOM}$ & $1.940^{\mathrm{bc} \mathrm{B}}$ & $8.01^{\mathrm{bcd} A}$ & $0.2613^{\mathrm{cA}}$ & $5.61^{\mathrm{cB}}$ \\
\hline $0.2 \% \mathrm{EOM}$ & $1.467^{\mathrm{c} \mathrm{B}}$ & $7.71^{\mathrm{cdA}}$ & $0.4229^{\mathrm{b} \mathrm{A}}$ & $6.60^{\mathrm{ab} A}$ \\
\hline $0.4 \% \mathrm{EOM}$ & $3.557^{\mathrm{a} \mathrm{B}}$ & $8.25^{\mathrm{ab} \mathrm{A}}$ & $0.3980^{\mathrm{bA}}$ & $6.60^{\mathrm{ab} B}$ \\
\hline $0.8 \%$ EOM & $1.791^{\text {bc B }}$ & $7.60^{\mathrm{dA}}$ & $0.5249^{\mathrm{aA}}$ & $6.83^{\mathrm{aB}}$ \\
\hline Fungicide & $4.005^{\mathrm{a} \mathrm{A}}$ & $8.15^{\mathrm{bcA}}$ & $0.3880^{\mathrm{bA}}$ & $6.13^{\mathrm{bB}}$ \\
\hline Bactericidal & $1.642^{\mathrm{bc} \mathrm{A}}$ & $7.94^{\operatorname{bcd} A}$ & $0.0548^{\mathrm{e} B}$ & $5.26^{\mathrm{cB}}$ \\
\hline
\end{tabular}

${ }^{1}$ Proportions followed by different lowercase letters in the column and uppercase in line are statistically different by Bayesian comparisons, at 5\% probability; EOM: essential oil of moringa.

The best results for first count (\%) for the cultivar Colibri were observed with the fungicide treatment and the dose corresponding to $0.4 \%$ EOM, which was statistically superior to the control treatment. This same dose also gave the best germination rates, as shown in Table 2, as well as the best GSI.

With the Campos Gerais cultivar, the doses corresponding to $0.8 \% \mathrm{EOM}$ and bactericide, respectively, resulted in the highest and lowest percentage for first count. The highest essential oil dose $(0.8 \%)$ increased the values of force of the bean seeds, as it showed a statistically significant higher result than the control treatment for the parameters first count and GSI.

This increase in the vigor of the treated seeds may be related to the antimicrobial activity of the essential oil of moringa, since the presence of pathogens in seeds directly affects force (ZORATO; HENNING, 2001), thus justifying the low seed vigor of treatments without the essential oil. Carvalho et al. (1999) stated that seeds predisposed to the action of microorganisms, when treated, reduce the survivability of pathogens and enhance their germination and vigor.

Ferreira and Borghetti (2004) pointed out that the allelochemicals of essential oil can often act on seed vigor (germination speed or some other parameter) confirming the results obtained in this experiment and also the results observed by Araújo Neto et al. (2012), where the essential oil of anise (Pimpinella anisum) at a concentration of $2.5 \%$ provided the highest percentage of germinated seeds of the first count.

With the exception of treatments with fungicide and bactericide on the Campos Gerais cultivar, the results were statistically higher than with Colibri for first count of seeds treated with essential oil of moringa, accentuating its effect on the less vigorous seeds.

The effect of the treatments containing essential oil of moringa, bactericide and fungicide was also evaluated in emergency bean seedlings and is illustrated in Figures 1 (emergency percentage) and 2 (emergency speed index).

Concerning the emergency \% (Figure 1) after treatment with different doses of EOM, this did not differ significantly for the Colibri cultivar. However, the results were statistically higher than those of the control treatment and bactericide and statistically equal to treatment with fungicide. It was observed that the essential oil of moringa and fungicide were equally effective in maintaining the viability of the seeds under real conditions in the field, ensuring fast crop establishment. 
Figure 1. Bayesian a posteriori estimates of the proportion of emergency percentage bean seed field according to the structured factors and cultivars.

Estimated proportion of emergency in field of bean seeds, according to the structured factors and cultivars

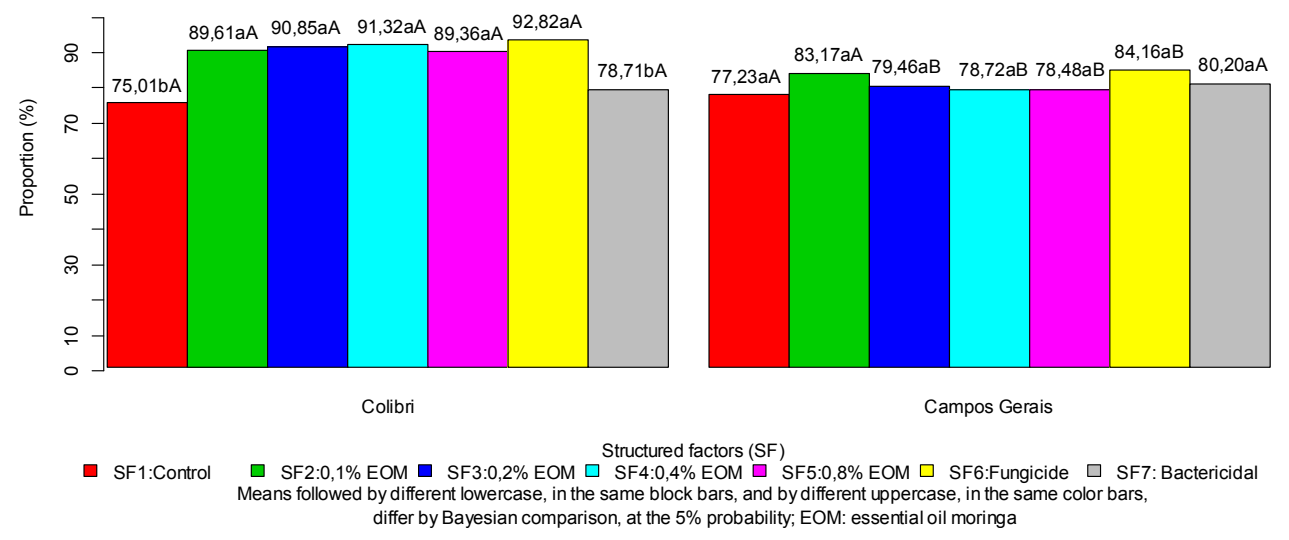

With seeds of the Campos Gerais cultivar, there was no effect of the different treatments on the percentage of seedlings in the field. This result differs from the results obtained for germination and IVG, where certain doses of essential oil from moringa were responsible for lower averages. According to White et al. (1989), it can be difficult to characterize allelopathy and its true impact unless factors of plant, soil and microorganisms are taken into account. For this reason, many authors agree

that one cannot extrapolate the results found in the laboratory to the field (SILVA et al., 2006).

For the GSI shown in Figure 2, it is observed that there was no statistical difference between the treatments for the Campos Gerais cultivar, unlike the cultivar Colibri, where the control and bactericidal treatments differed from the others.

As to the effect of the essential oil on the cultivars, there was a statistical difference in the percentage of emergence with treatments $0.2 \%, 0.4 \%$, and $0.8 \%$ EOM and fungicide only on the Colibri cultivar.

Figure 2. Bayesian a posteriori estimates of the proportion of emergency percentage bean seed field according to the structured factors and cultivars.

Estimated average of speed emergence index of bean seed field according to the structured factors and cultivars

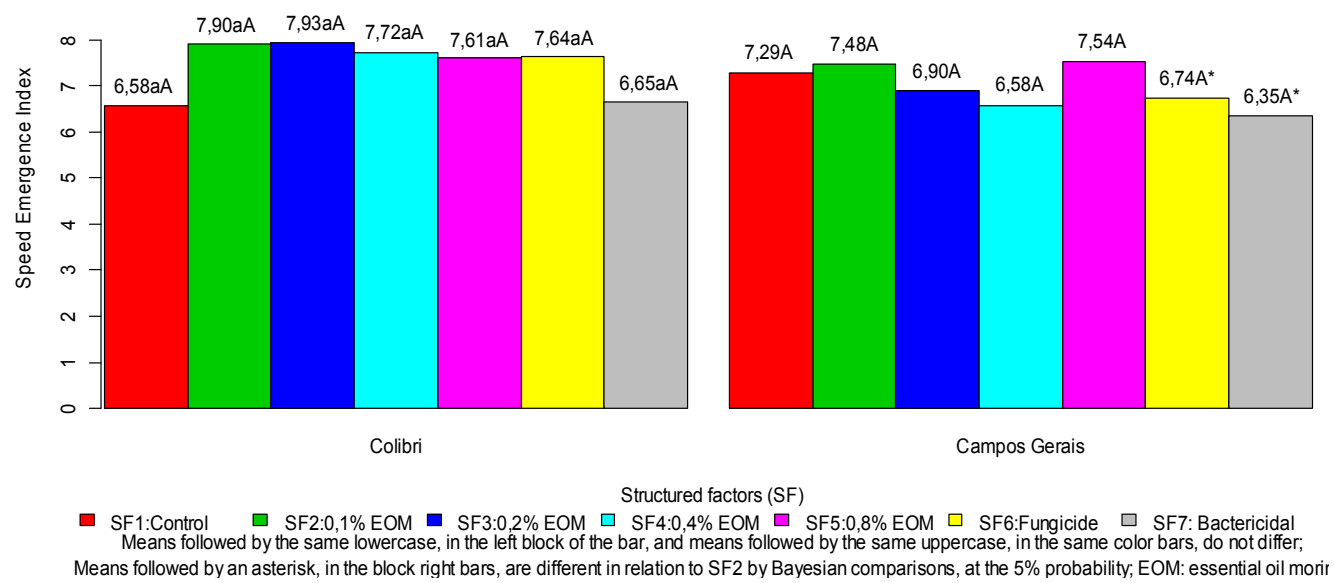




\section{Isoenzyme electrophoresis}

The enzyme systems of bean seeds subjected to treatment with different doses of essential oil of moringa, fungicide and bactericide were revealed for esterase (EST), isocitrate lyase (ICL), alcohol dehydrogenase $(\mathrm{ADH})$ and superoxide dismutase (SOD); these are presented Figure 3.
By zymogram of esterase enzyme (Figure 3a), we observed lower expression in the treatments on the Campos Gerais cultivar with $0.8 \%$ OEM and fungicide, and on the Colibri cultivar in treatments with bactericide, fungicide, 0.0 and $0.4 \%$ OEM. This result differs from that found by Muniz et al. (2007), who reported no changes in the activity of esterase under different sedge extract concentrations during the germination of bean seeds.

Figure 3. Electrophoretic profile revealed polyacrylamide gel for isoenzymes: esterase (A), isocitrate lyase (B), alcohol dehydrogenase (C), and superoxide dismutase (D) extracted from bean seeds of cultivars Campos Gerais and Colibri treated with fungicide, bactericide and different doses $(0,0.1,0.2,0.4$ and $0.8 \%)$ essential oil of moringa.
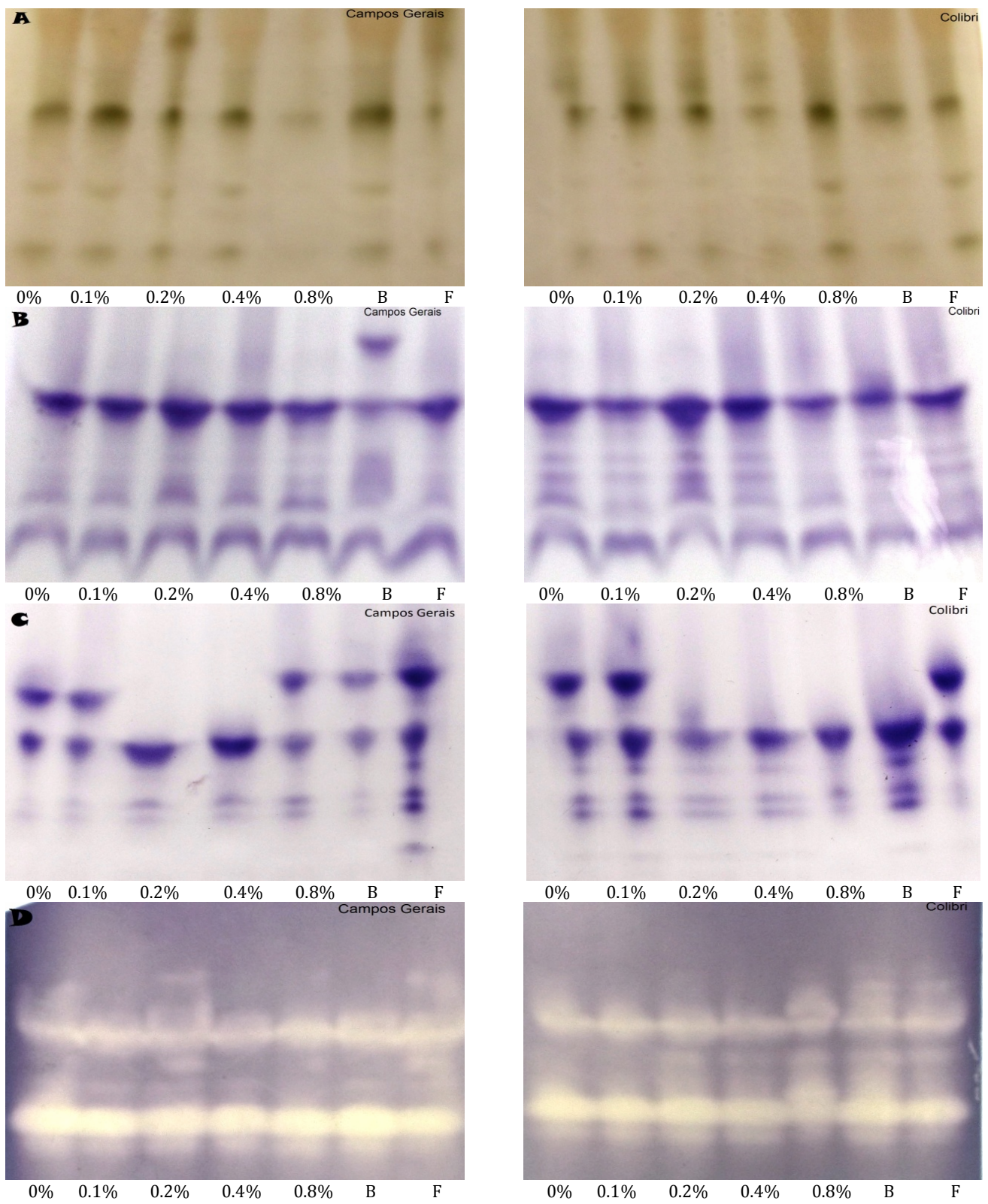
The esterase enzyme system presents with monomeric variants or as dimeric with a high level of variability, being one of the most polymorphic systems in plants (WEEDEN; WENDEL, 1990). Changes in the patterns of this enzyme are evidence of the occurrence of deteriorative events, considering their involvement in ester hydrolysis reactions, and can be directly linked to lipid metabolism and degenerative processes in membranes (SANTOS et al., 2004); therefore, its low expression may lead to a reduction in seed germination, according to Basavarajappa et al. (1991).

The $0.8 \%$ EOM doses on the Campos Gerais cultivar and $0.4 \%$ EOM on the Colibri cultivar possibly acted as antioxidants, preventing deteriorative events related to the metabolism of lipids, which is in line with the germination tests (Table 2), where the same treatments yielded the highest percentage of germination. In turn, where there was hgher expression of enzyme bands for both cultivars, there was greater lipid peroxidation and consequently the lowest percentage of germination.

The antioxidant activity of moringa was cited by Sreelatha and Padma (2009). In the study conducted by the authors, an aqueous extract of the leaves of this plant showed a strong killing effect on superoxide radicals, nitric oxide radicals and the inhibition of lipid peroxidation.

Note that variations in the electrophoretic profile of this enzyme are also related to the seed association of microorganisms, as noted by Brandão-Junior et al. (1999), who observed the appearance of new bands due to the action of fungi in storage corn seeds.

Regarding the expression of the enzyme isocitrate lyase (ICL) (Figure 3b), there was less expression in the treatments with the bactericidal and $0.8 \%$ EOM onthe Campos Gerais cultivar and 0.1 and $0.8 \%$ EOM in the case of the Colibri cultivar. This enzyme, together with malate synthase, is related to legumes, the conversion of carbohydrates into lipids through the glyoxylate cycle. The transformation of lipids into sucrose by the enzyme is important in the germination process (MAYER; POLJAKOFFMAYBER, 1989).

The reduced enzyme activity observed in these treatments is related to seed vigor, since they had lower GSI. This fact confirms the suggestion of Martins et al. (2000) that an increased activity in this enzyme may be related to more vigorous seeds.

The enzyme alcohol dehydrogenase (ADH), observed in Figure 3c, is a dimeric enzyme according to Pasteur et al. (1988) that acts in the respiratory process, removing toxic substances to seeds such as the acetaldehyde and ethanol produced when cells start to breathe anaerobically (FARIA et al., 2003).

The ADH system showed low polymorphism in seeds of the Campos Gerais cultivar, revealing the presence of three bands in three regions of activity depending on the processing undergone. Both the intensity and number of bands changed due to treatment with the essential oil, fungicide and bactericide.

Region 1 showed greater migration and lower molecular weight bands with all treatments. However, with the $0.8 \%$ dose and fungicidal EOM, there was significantly different expression compared to the control treatment, which, together with the lower dose of essential oil $(0.1 \%)$, had two bands (regions 1 and 2). Region 3, with the highest molecular weight band, was present only for treatments with $0.4 \% \mathrm{EOM}$, fungicide and bactericide.

In the Colibri cultivar, bands for $\mathrm{ADH}$ were present and distributed in two regions (1 and 3) for the control treatment, $0.1 \%$ EOM and fungicide, and bands in only a single region (1) for treatments with $0.2,0.4$ and $0.8 \% \mathrm{EOM}$, varying in intensity and differentiated from the control treatment. The reduced expression occurred in the treatments with $0.2 \%$ and $0.4 \%$ EOM, indicating reduced activity of the enzyme in essential oil function.

With respect to the essential oil doses, it is noted that these changes are responsible for the molecular forms of $\mathrm{ADH}$. Given its protective function against 
acetaldehyde, which accelerates the deterioration of seeds, it is inferred that the reduced intensity of the bands observed in treatments above in both cultivars may be related to lower anaerobic respiration activity; simultaneously, such treatments also had the highest germination rates (Table 2).

Considering that, during the germination process, the respiratory metabolism and $\beta$-oxidation are the main sources of reactive oxygen species (ROS), due to the fact that plant photosynthesis may not be independent (XI et al., 2010), pronounced SOD activity was observed (Figure 3-D) in all treatments, with little increase in seeds from the control treatment and bactericide(Campos Gerais) or in those receiving the $0.8 \%$ OEM dose and bactericide (Colibri). The small variation observed may also be related to the fact that the enzyme is present in organelles such as mitochondria and chloroplasts, as well as the cytoplasm, which confer stability to the enzyme (NEWTON et al., 1999).

This enzyme catalyzes the conversion of the free radical superoxide $\left(\mathrm{O}^{-}\right)$, produced at different locations in the cell, to molecular oxygen and $\mathrm{H}_{2} \mathrm{O}_{2}$ (RABINOWITCH; FRIDOVICH, 1983).

Harter et al. (2014) reported that an increase in superoxide production causes difficulties in germinating seeds normally. This fact corroborates the results of this work, as the treatments in which there was a greater expression of SOD were associated with the lowest percentage of germination in both cultivars.

\section{Conclusion}

The essential oil of Moringa oleifera at a rate of $0.4 \%$ was able to promote the highest average germination, emergence and vigor of bean seeds of the Colibri cultivar. However, the highest dose used $(0.8 \%)$ was phytotoxic, accounting for a reduction in physiological quality (\% G, first count and GSI).

The Campos Gerais cultivar that had an evaluation of initial quality, low vigor and germination, suffered the greatest influence of essential oil doses, stimulating germination and ensuring greater force to the seeds.

There was no change in the GSI according to EOM doses; however, the essential oil chemical composition of Moringa oleifera was responsible for changes in the molecular forms of the enzymes EST, ICL, ADH and SOD, the values of which are linked to physiological seed quality.

\section{References}

AlbuQuerque, K. S.; GUIMARÃES, R. M.; ALMEIDA, I. F.; CLEMENTE, A. C. S. Alterações fisiológicas e bioquímicas durante a embebição de sementes de sucupira-preta (Bowdichia virgilioides Kunth). Revista Brasileira de Sementes, Londrina, v. 31, n. 1, p. 12-19, 2009.

ALFENAS,A.C.;PETERS, I.;BRUNE, W.;PASSADOR, G. C. Eletroforese de proteinas e isoenzimas de fungos e essências florestais. Viçosa, MG: UFV, 1996. 242 p.

AN, M.; HOHNSON, I. R.; LOVETT, J. V. Mathematical modelling allelopathy: biological response to allelochemical and its interpretation. Journal of Chemical Ecology, Iowa, v. 19, n. 19, p. 2379-2389, 1993.

ARAÚJO NETO, A. C.; ARAÚJO, P. C.; SOUZA, W. C. O.; MEDEIROS, J. G. F.; AGUIAR, A. V. M. Óleo essencial de anis na incidência e controle de patógenos em sementes de erva-doce (Foeniculum vulgare Mill.). Revista Verde, Pombal, v. 7, n. 1, p. 170-176, 2012.

BASAVARAJAPPA, B. S.; SHETTY, H. S.; PRAKASH, H. S. Membrane deterioration and other biochemical changes associated with accelerated ageing of maize seeds. Seed Science and Technology, Cambridge, v. 19, n. 2, p. 279-286, 1991.

BRANDÃO-JUNIOR, D. S.; CARVALHO, M. L. M.; VIEIRA, M. G. G. C. Variações eletroforéticas de proteínas e isoenzimas relativas à deterioração de sementes de milho envelhecidas artificialmente. Revista Brasileira de Sementes, Londrina, v. 21, n. 1, p. 114-121, 1999.

BRASIL. Associação Brasileira de sementes e mudas. Instrução normativa $\mathrm{n}^{\circ}$ 9, de 2 de Junho de 2005. Diário Oficial [da] República Federativa do Brasil, Brasília, DF, 2 jun. 2005. Seção XLIII, p. 1-77.

.Ministério da Agricultura, Pecuária e Abastecimento. Regras para análise de sementes. 
Brasília: Secretaria de Defesa Agropecuária, MAPA/ ACS, 2009. 39 5p.

AGROFIT 2003: Sistema de informação. Brasília, DF, 2003. Seção 1, p. 1-60. Disponível em: $<$ http://agricultura.gov.br/agrofit $>$. Acesso em: 09 abr. 2014.

CAETANO, A. C.; CHAMMA, K. L.; FERREIRA, L. C.; DÉSTRO, G. F. G.; SOUSA, D. C. F. Atividade de superóxido dismutase em plantas de soja (Glycine Max L.) cultivadas sob estresse oxidativo causado por herbicida. Revista Brasileira de Herbicidas, Londrina, v. 4, n. 2, p.14-23, 2005.

CARVALHO, R. A.; CHOAIRY, S. A.; LACERDA, J. T.; OLIVEIRA, E. F. Effect of plants with antibiotic properties on the control of Fusarium sp. In.: INTERNATIONAL PLANT PROTECTION CONGRESS, 1999, Israel. Proceeding... Israel: Millenium, 1999. p. 19-25.

COMPANHIA NACIONAL DE ABASTECIMENTO CONAB. Acompanhamento da safra brasileira de grãos. Brasília: Sumac, 2014. Disponível em: <http://www. conab.gov.br>. Acesso em: 28 jul. 2014.

FARIA, L. C.; COSTA, J. G. C.; RAVA, C. A.; PELOSO, M. J. D.; MELO,L. C.; CARNEIRO, G. E. S.; SOARES, D. M.; DÍAZ, J. L. C.; ABREU, A. F. B.; FARIA, J. C.; SARTORATO, A.; SILVA, H. T.; BASSINELLO, P. Z.; ZIMMERMANN, F. J. P. BRS Requinte: nova cultivar de feijoeiro comum de tipo de grão carioca com retardamento do escurecimento do grão. Santo Antônio de Goiás: EMBRAPA Arroz e Feijão, 2003. 4 p. (Comunicado técnico, 65).

FERREIRA, A. G.; AQUILA, M. E. A. Alelopatia: Área emergente da ecofisiologia. Revista Brasileira de Fisiologia Vegetal, Lavras, v. 12, p. 175-204, 2000. (Edição Especial).

FERREIRA, A. G.; BORGHETTI, F. Germinação: do básico ao aplicado. Porto Alegre: Artmed, 2004. 323 p.

GALVÃO, J. C. C.; CONCEIÇÃO, P. M.; ARAÚJO, E. F.; KARSTEN, J.; FINGER, F. L. Alterações fisiológicas e enzimáticas em sementes de milho submetidas a diferentes épocas de semeadura e métodos de debulhas. Revista Brasileira de Milho e Sorgo, Sete Lagoas, v. 13, n. 1, p. 14-23, 2014.

GROSSO, C.; COELHO, J. A.; URIETA, J. S.; PALAVRA, A. M. F.; BARROSO, J. G. Herbicidal activity of volatiles from coriander, winter savory, cotton lavender, and thyme isolated by hydrodistillation and supercritical fluid extraction. Journal of Agricultural and Food Chemistry, Kansas, v. 58, n. 20, p. 11007-11013, 2010.
HARTER, L. S. H.; HARTER, F.; DEUNER, C.; MENEGHELLO, G.; VILLELA, F. A. Salinidade e desempenho fisiológico de sementes e plântulas de mogango. Horticultura Brasileira, Vitória da Conquista, v. 32, n. 1, p. 80-85, 2014.

HEIDELBERGER, P.; WELCH, P. Simulation run length control in the presence of an initial transient. Operations Research, New York, v. 31, n. 6, p. 1109-1144, 1983.

ISMAN, M. B.; WAN, A. J.; PASSREITER, C. M. Insecticidal activity of essential oils to the tobacco cutworm, Spodoptera litura. Fitoterapia, Novara, v. 72, n. 1, p. 65-68, 2001.

MAGUIRE, J. D. Speeds of germination-aid selection and evaluation for seedling emergence and vigor. Crop Science, Madison, v. 2, n. 2, p. 176-177, 1962.

MAIRESSE, L. A. S. Avaliação da bioatividade de extratos de espécies vegetais, enquanto excipientes de aleloquímicos. 2005. Tese (Doutorado em Agronomia) - Centro de Ciências Rurais. Universidade Federal de Santa Maria, Santa Maria.

MARTINS, C. A. O.; SEDIYAMA, C. S.; OLIVEIRA, M. G. A.; JOSÉ, I. C.; MOREIRA, M. A. Atividade da isocitrato-liase durante a germinação de sementes de soja. Revista Brasileira de Sementes, Londrina, v. 22, n. 1, p. 42-46, 2000.

MAYER, A. M.; POLJAKOFF-MAYBER. The germination of seeds. $3^{\text {th }}$ ed. New York: Pergamon Press, 1989. $236 \mathrm{p}$.

MAZZAFERA, P. Efeito alelopático do extrato alcoólico de cravo-da-índia e eugenol. Revista Brasileira de Botânica, São Paulo, v. 26, n. 2, p. 231-238, 2003.

MENEZES, M.; VON PINHO, E. V. R.; PEREIRA, A. M. A. R.; OLIVEIRA, J. A. Identificação de cultivares de milho, feijão, algodão e soja por meio de enzimas e proteínas resistentes ao calor. Revista Brasileira de Sementes, Londrina, v. 30, n. 2, p. 111-122, 2008.

MIGLIORINI, P.; KULCZYNKI, S. T.; SILVA. T. A.; BELLÉ, C.; KOCH, F. Efeito do tratamento químico e biológico na qualidade fisiológica e sanitária de semente de canola. Enciclopédia Biosfera, Goiânia, v. 8, n. 15, p. 788-801, 2012.

MUNIZ, F. R.; CARDOSO, M. G.; VON PINHO, E. V. R.; VILELA, M. Qualidade fisiológica de sementes de milho, feijão, soja e alface na presença de extrato de tiririca. Revista Brasileira de Sementes, Londrina, v. 29, n. 2, p. 195-204, 2007.

NAKAGAWA, J. Testes de vigor baseados na avaliação das plântulas. In: VIEIRA, R. D.; CARVALHO, N. M. Testes de vigor em sementes. Jaboticabal: FUNEP, 1994. p. 49-85. 
NEWTON, A. C.; ALLNUTT, T. R.; GILLIES, A. C. M.; LOWE, A. J.; ENNOS, R. A. Molecular phylogeography, intraspecific variation and the conservation of tree species. Trends in Ecology and Evolution, London, v. 14, n. 4, p. 140-145, 1999.

PASTEUR, N.; PASTEUR, G.; BONHOME, F. Pratical isozyme genetics. New York: Haslted Press, 1988, 255 p.

PAUDEL, V. R.; GUPTA, V. N. P. Effect of some essential oils on see genotoxiced germination and seedling length of Parthenium hysterophorous L., Ecoprint: An international Journal of Ecology, Nepal, v. 15, n. 2, p. 69-73, 2008.

R DEVELOPMENT CORE TEAM - R. A language and environment for statistical computing. R Foundation for Statistical Computing, Vienna: Denmark, 2007 Disponível em :<http://www.R-project.org/>. Acesso em: 11 out. 2014.

RABINOWITCH, H. D.; FRIDOVICH, I. Superoxide radicals, superoxide dismutases and oxygen toxicity in plants. Photochemistry Photobiology, New York, v. 37, n. 1, p. 679-690, 1983.

RIZVI, S. J. N.; RIZVI, V. Allelopathy: basic and applied aspects. London: Chapman \& Hall, 1992. 480 p.

ROSADO, L. D. S.; RODRIGUES, H. C. A.; PINTO, J. E. B. P.; CUSTÓDIO, T. N.; PINTO, L. B. B.; BERTOLUCCI, S. K. V. Alelopatia do extrato aquoso e do óleo essencial de folhas do manjericão Maria Bonita na germinação de alface, tomate e melissa. Revista Brasileira de Plantas Medicinais, Botocatu, v. 11, n. 4, p. 422-428, 2009.

SANTOS, C. M. R.; MENEZES, N. L.; VILLELA, F. A. Alterações fisiológicas e bioquímicas em sementes de feijão envelhecidas artificialmente. Revista Brasileira de Sementes, Londrina, v. 26, n. 1, p. 110-119, 2004.

SECRETARIA DE ESTADO DA AGRICULTURA E DO ABASTECIMENTO - SEAB. Feijão: análise da conjuntura agropecuária. Brasília: Secretaria de Defesa Agropecuária, out. 2012. Disponível em <http://www. agricultura.pr.gov.br/arquivos/File/deral/Prognosticos/ feijao_2012_13.pdf>. Acesso em: 16 jul. 2013.

SILVA, G. C.; GOMES, D. P.; KRONKA, A. Z.; MORAES, M. H. Qualidade fisiológica e sanitária de sementes de feijoeiro (Phaseolus vulgaris L.) provenientes do estado de Goiás. Semina: Ciências Agrárias, Londrina, v. 29, n. 1, p. 29-34, 2008.
SILVA, W. A.; NOBRE, A. P.; LEITES, A. P.; SILVA, M. S. C.; LUCAS, R. C.; RODRIGUES, O. G. Efeito alelopático de extrato aquoso de Amburana cearensis Smith na germinação e crescimento de sementes de sorgo (Sorghum bicolor L.). Agropecuária Científica no Semiárido, Campina Grande, v. 2, n. 1, p. 48-54, 2006.

SREELATHA, S.; PADMA, P. R. Antioxidant activity and total phenolic content of Moringa oleifera leaves in two stages of maturity. Plant Foods for Human Nutrition, Maine, v. 64, n. 4, p. 303-311, 2009.

STEFFEN, R. B.; ANTONIOLLI, Z. I.; STEFFEN, G. P. $\mathrm{K}$. Efeito estimulante do óleo essencial de eucalipto na germinação e crescimento inicial de mudas de Eucalyptus grandis. Pesquisa Florestal Brasileira, Colombo, v. 30, n. 63, p. 199-206, 2010.

XI, Z. M.; ZHANG, Z. W.; CHENG, Y. F.; HUA, L. The effect of vineyard cover crop on main monomeric phenols of grape berry and wine in Vitis vinifera L. cv. Cabernet Sauvignon. Agricultural Sciences in China, Yangling, v. 9, n. 3, p. 440-448, 2010.

WEEDEN, N. F.; WENDEL, J. F. Genetics of plant isozymes. In: SOLTIS D. E.; SOLTIS P. S. (Ed.). Isozymes in plant biology. London: Chapman and Hall, 1990. p. 46-72.

WEIDENHAMER, J. D.; MACIAS, F. A.; FISCHER, N. H.; WILLIAMSON, B. Just how insoluble are monoterpenes? Journal of Chemistri Ecolology, Iowa, v. 19, n. 8, p. 1799-1807, 1993.

WHITE, R. H.; WORSHAM, A. D.; BLUM, U. Allelopathic potencial of legume debris and aqueous extracts. Weed Science, Lawrence, v. 37, n. 5, p. 674-679, 1989.

ZORATO, M. F.; HENNING, A. A. Influência de tratamentos com fungicidas antecipados, aplicados em diferentes épocas de armazenamento, sobre a qualidade de sementes de soja. Revista Brasileira de Sementes, Londrina, v. 23, n. 2, p. 236-244, 2001.

ZORATO, M. F.; PESKE, S. T.; TAKEDA, C.; FRANÇA NETO, J. B. Sementes esverdeadas em soja: testes alternativos para determinar a sua qualidade. Revista Brasileira de Sementes, Londrina, v. 29, n. 1, p. 1-10, 2007. 